\title{
Quantitative Analysis of Tree Species Diversity in Different Oak (Quercus spp.) Dominated Forests in Garhwal Himalaya, India
}

\author{
Gajendra SINGH ${ }^{1 *}$, Gopal S. RAWAT² \\ ${ }^{1}$ Wildlife Institute of India, PO Box 18, Chandrabani, 248001 Dehradun, Uttarakhand, India; gajendrawat@yahoo.com (*corresponding author) \\ ${ }^{2}$ International Centre for Integrated Mountain Development, Ecosystem Services, GPO Box 3226, Kathmandu, Nepal
}

\begin{abstract}
Himalayan broad-leaved forests are mainly dominated by oak (Quercus spp.) species. Oak species with other tree species provide numerous ecosystem services and serve as lifeline for local inhabitants. Overall tree diversity and their status in different oak dominated forests viz., Quercus leucotrichophora (1500-2200 m), Q. floribunda (2201-2700 m) and Q. semecarpifolia (2701-3300 m) were studied in Garhwal, Himalaya. A total of 54 tree species (40 genera) in Q. leucotrichophora, 43 tree species (30 genera) in Q. floribunda and 23 tree species (16 genera) in Q. semecarpifolia dominated forests were recorded. Lauraceae was the dominant family in Q. leucotrichophora and Q. floribunda forests (6 and 8 species respectively), while Ericaceae ( 3 species) was the dominant family in Q. semecarpifolia dominated forests. Pinaceae and Taxaceae were only two gymnospermic family represented by Pinus roxburghii at low, Abies pinrow at mid, Abies spectabilis and Taxus wallichiana at higher elevational oak forests. There was no significant variation $(p=0.8)$ between overall tree density in different oak forests which ranges from $337 \pm 51$ individual/ha in Q. semecarpifolia to $433 \pm 92$ individual/ha in Q. leucotrichophora forests. The seedling density has significant variation $(p=0.01)$ in different oak forests where highest density was recorded in Q. leucotrichophora forests (1981 individual/ha) and lowest in Q. semecarpifolia forests (348 individual/ha). The Total Basal Area (TBA) reported from Q. leucotrichophora $\left(88.06 \mathrm{~m}^{2} / \mathrm{ha}\right)$ and Q. floribunda $\left(110.5 \mathrm{~m}^{2} / \mathrm{ha}\right.$ ) forests was higher than those of earlier reported from the region, while basal area of Q. semecarpifolia $\left(90.16 \mathrm{~m}^{2} / \mathrm{ha}\right)$ was comparable with the forests of western Himalaya.
\end{abstract}

Keywords: associated species, elevation, oak forests, population, regeneration

\section{Introduction}

Oaks (Quercus spp.) are the dominant, climax tree species of the moist temperate forests of the Indian $\mathrm{Hi}$ malayan region (Troup, 1921) where about 35 species of Quercus are extensively distributed between 1000-3500 m elevations. Five species of evergreen oaks, namely Quercus glauca (phaliyant/harinj), Q. leucotrichophora (banj), Q. lanuginosa (rianj), Q. floribunda (tilonj/moru) and $Q$. semecarpifolia (brown/kharsu) grow naturally in the Uttarakhand state. Except Q. glauca and Q. lanuginosa three species are widely distributed and forms extensive patches in the Garhwal Himalaya (Singh and Singh, 1992) and each species is replaced by the other to form the climax communities along an increasing elevation. At $2000 \mathrm{~m}$ and less Q. leucotrichophora exhibits $80 \%$ dominance (based on relative basal area), between 2000 to $2200 \mathrm{~m}$ it may share dominance with Q. floribunda and above 2200 $m$ it generally disappears (Singh and Singh, 1992; Zobel and Singh, 1997). In small patches between $2100-2400 \mathrm{~m}$, Q. floribunda may show clear-cut dominance but with further increase in elevation, $Q$. floribunda is replaced by $Q$. semecarpifolia, which may show more than $70-80 \%$ domi- nance in oak forests located above $2700 \mathrm{~m}$ a.s.l. (Ralhan et al., 1982).

Oak species assume considerable conservation significance in the Himalayan region as they are providers of numerous ecosystem services and serve as lifeline for the local communities (Saxena and Singh, 1982; Singh and Singh, 1986, 1987; Upreti et al,. 1985). The oaks, particularly $Q$. leucotrichophora, Q. floribunda and Q. semecarpifolia are intricately associated not only with agro-ecosystems but also with the life support systems of the inhabitants of the hills in the Himalaya. The oak forests are source of fuelwood, timber and can be correlated with natural springs and wildlife (Singh, 1981). Himalaya is the home of many unique and diverse human groups, living in river valleys and mountain slopes between 1000-2200 m elevations and subsisting on the Himalayan natural resources for thousands of years. In the recent few decades, with better access to global market and demand for socio-economic development, local people's dependence on natural resources has increased immensely. Therefore, high richness and distribution of associated species is more important for the long term sustainability of these valuable oak species. 
Ecological studies covering community structure and phytosociology of the oak forests are largely confined to Kumaun Himalaya (Ralhan et al., 1982; Singh and Singh, 1987, 1992). These authors have found that throughout the elevational gradient, evergreen Quercus spp. are the dominant tree species sharing dominance with evergreen and deciduous species viz., Alnus nepalensis, Carpinus viminea, Lyonia ovalifolia. Through aerial photo-analysis Tiwari and Singh (1984) described four different oak forests in the Kumaun region, where Q. leucotrichophora occupied maximum area, while Q. floribunda occupied the minimum. Total basal area for the central and western $\mathrm{Hi}$ malayan oak forests were reported to range between 29.8 to $83.8 \mathrm{~m}^{2} / \mathrm{ha}$ (Saxena and Singh, 1982; Singh and Singh, 1986, 1987; Tewari and Singh, 1984). In the forests where oaks were prevalent the total basal cover ranged between 29.3 to $39.2 \mathrm{~m}^{2} / \mathrm{ha}$ (Rawat and Singh, 1988; Upreti et al. 1985). These authors also reported that in natural banj oak forests the species richness is low, where generally one or two species predominate. Several studies on diversity, population structure, regeneration status and causes of degradation of the central Himalayan oak forests concluded that excessive dependency and exploitation is the major concern for rapid degradation (Chandra et al., 1989; Gupta and Singh, 1962; Rikhari et al., 1989; Saxena and Srivastava 1973; Singh and Singh 1987). The literature review reveals that a few studies are available in complete quantification of tree species diversity and status in various oak forests from the Garhwal Himalaya. The present study describes: 1) tree species diversity in various oak forests, 2) population status of oaks and its associated species in these oak dominated forests within an elevational range of 1400-3300 m in Garhwal, Himalaya.

\section{Materials and methods}

\section{Study area}

The study was conducted in the outer fringes of Kedarnath Wildlife Sanctuary (KWS) in Chamoli and Rudraprayag districts, Garhwal Himalaya. Historically, the area has been a famous place of pilgrimage for Indian devotees for many centuries. A motorable road connects this area to the nearby national highway and other religious places (Kedarnath, Badrinath, Gangotri and Yamunotri). The area is characterized by undulating topography, wide variation in altitude, rainfall, temperature and soil conditions. The area is an important wintering range of several high altitude animals and is used by a large number of local agro-pastoral and migratory community (gujjars) besides tourists and pilgrims during summer. The intensive study area $\left(\sim 975 \mathrm{~km}^{2}\right)$ covers a wide elevational range from $1400-3680 \mathrm{~m}$ above sea level with a varying mean annual temperature range $\left(-4\right.$ to $\left.34^{\circ} \mathrm{C}\right)$. The local inhabitants are settled in scattered villages along lower fringes $(<2200 \mathrm{~m})$ and are basically agro-pastoralists. Livestock production and tourism are the main landuse practices across different elevational zones in the region. The area was selected as it has a wide elevational range, different habitat and vegetation types mainly dominated by the oaks, varied aspect and slope categories. According to Champion and Seth (1968) broad vegetation classes in the study area are Temperate Oak Forest, Maple Forest, Sub- Alpine Oak Forest, Fir Forest, Birch- Buransh Forest, Alpine scrub, and Alpine meadows.

\section{Methods}

The field surveys were carried out to study the tree species across various oak forests in the outer fringes of Kedarnath WS during 2006 to 2010. Based on six months of extensive reconnaissance survey and dominance of oak species, three types of forests viz., Q. leucotrichophora (1400-2200 m), Q. floribunda (2201-2700 m) and Q. semecarpifolia (2701-3300 m) were taken up for the vegetation analysis (Fig. 1). Vegetation sampling procedures were determined following Mishra (1968) and Kershaw (1973). Avoiding main motorable road, permanent foot paths and fodder collection trails, various forested and other habitats in each oak forests were identified and marked. Transects were laid within these forests covering various altitude, aspects and slope categories. 10 sample plots were taken in each transect, at an interval of $200 \mathrm{~m}$ depending upon the accessibility. Overall, 287 circular plots were laid in three oak forests. Although maximum efforts were made to include all the representative areas of oak forests but some of the inaccessible areas were difficult to cover due to steep slopes $\left(>60^{\circ}\right)$. Within each plot, circumference at breast height $(\mathrm{CBH})$ of each tree, height, species name and number were recorded. A nested plot of a $5 \mathrm{~m}$ radius $\left(78.5 \mathrm{~m}^{2}\right.$ area) was laid within the larger plot to record regenerating individuals (seedlings and saplings). Identification of plants was made with the help of florulas, research papers and reports (e.g., Naithani, 1984; Polunin and Stainton, 1984; Osmaston, 1927). Unidentified plants were collected and preserved following Jain and Rao (1976) and brought to Wildlife Institute of India (WII) Dehra Dun for further examination and identification. Herbarium of WII, Botanical Survey of India, Northern circle Dehra Dun (BSI) and Forest Research Institute Dehra Dun (DD) were consulted to cross-check the identity of various species. A set of duplicate specimens were collected for

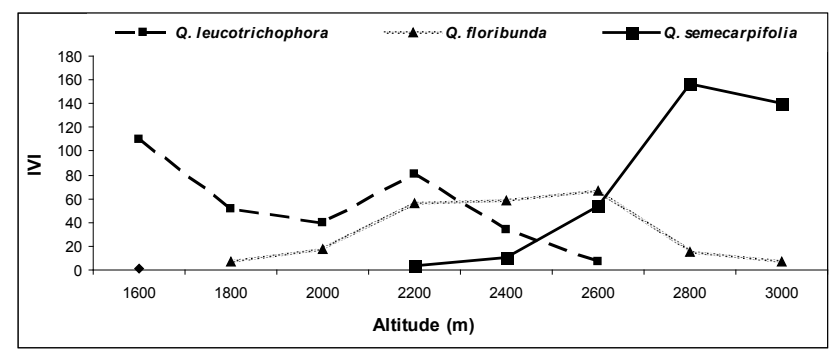

Fig. 1. Dominance (IVI) of oak species at different altitude in Kedarnath WLS, Garhwal Himalaya 
Tab. 1. Number of tree species and their density (individuals/ha) of important families in various oak forests

\begin{tabular}{|c|c|c|c|c|c|c|}
\hline \multirow{2}{*}{ Families } & \multicolumn{2}{|c|}{$\begin{array}{c}\text { Q. leucotrichophora } \\
\text { forest }\end{array}$} & \multicolumn{2}{|c|}{$\begin{array}{l}\text { Q. floribunda } \\
\text { forest }\end{array}$} & \multicolumn{2}{|c|}{$\begin{array}{c}\text { Q. semecarpifolia } \\
\text { forest }\end{array}$} \\
\hline & $\begin{array}{l}\text { No. of } \\
\text { Species }\end{array}$ & $\begin{array}{l}\text { Density } \\
\text { (ind./ha) }\end{array}$ & $\begin{array}{l}\text { No. of } \\
\text { Species }\end{array}$ & $\begin{array}{l}\text { Density } \\
\text { (ind./ha) }\end{array}$ & $\begin{array}{l}\text { No. of } \\
\text { Species }\end{array}$ & $\begin{array}{l}\text { Density } \\
\text { (ind./ha) }\end{array}$ \\
\hline Aceraceae & 2 & 1.38 & 4 & 18.05 & 2 & 0.85 \\
\hline Anacardiaceae & 3 & 3.46 & 1 & 0.27 & - & - \\
\hline Aquifoliaceae & 1 & 3.46 & 1 & 19.11 & 1 & 2.97 \\
\hline Betulaceae & 4 & 43.27 & 3 & 15.13 & 1 & 0.42 \\
\hline Buxaceae & - & - & 1 & 1.33 & - & - \\
\hline Celastraceae & - & - & 1 & 2.12 & - & - \\
\hline Cornaceae & 2 & 1.04 & - & - & - & - \\
\hline Ericaceae & 2 & 118.73 & 1 & 164.81 & 3 & 136.73 \\
\hline Euphorbiaceae & 3 & 32.19 & - & - & - & - \\
\hline Fagaceae & 3 & 88.27 & 3 & 117.30 & 2 & 146.92 \\
\hline Hippocastanaceae & - & - & 1 & 4.25 & - & - \\
\hline Lauraceae & 6 & 67.16 & 8 & 40.07 & 2 & 2.55 \\
\hline Meliaceae & 2 & 1.04 & 1 & 0.27 & - & - \\
\hline Moraceae & 3 & 0.69 & - & - & - & - \\
\hline Myricaceae & 1 & 11.42 & - & - & - & - \\
\hline Oleaceae & - & - & 2 & 0.80 & - & - \\
\hline Pinaceae & 1 & 1.38 & 2 & 10.88 & 2 & 32.27 \\
\hline Rhamnaceae & 1 & 0.35 & - & - & 1 & 0.42 \\
\hline Rosaceae & 4 & 15.23 & 2 & 6.63 & 2 & 6.79 \\
\hline Sabiaceae & 2 & 5.88 & 1 & 0.53 & - & - \\
\hline Simaroubaceae & - & - & 1 & - & - & - \\
\hline Symplocaceae & 2 & 16.27 & 3 & 19.37 & 1 & 1.27 \\
\hline Taxaceae & - & - & 1 & 1.06 & 1 & 2.12 \\
\hline Others & 12 & 22.48 & 5 & 11.18 & 5 & 4.66 \\
\hline Total & 54 & 433.72 & 43 & 433.15 & 23 & 337.99 \\
\hline
\end{tabular}

less known and unidentifiable species preserved at WII's herbarium.

\section{Data analysis}

The field data was quantitatively analysed for frequency, density and basal area following the standard ecological methods (Muller-Dombois and Ellenberg, 1974). The Importance Value Index (IVI) for tree species was deter-

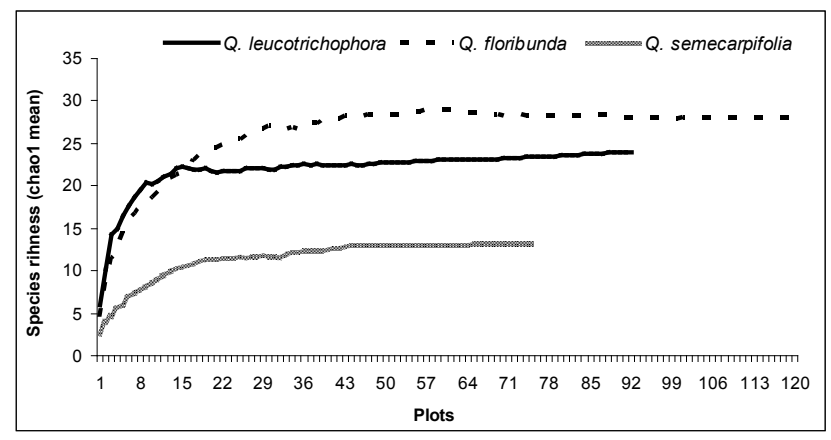

Fig. 2. Rarefaction graph of species richness across various oak forests mined as the sum of relative frequency, relative density, and relative basal area (Mishra, 1968). Species richness, the number of species per unit area (Whittaker, 1972), Shannon-Wiener Index of diversity (H') (Shannon and Weaver, 1972) and the mostly used Pielou's Evenness Index (Pielou, 1966) for the Himalayan region were also calculated. One way ANOVA was performed to test whether the densities of trees and regenerating individuals in the different oak forests are significantly different.

\section{Results}

\section{Species richness, diversity and distribution}

A wide range of tree species was recorded in the systematically surveyed three oak forests along the altitudinal gradient. A total of 54 tree species belonging to 40 genera and 26 families were recorded in Q. leucotrichophora dominated forests, while only 32 species $(59 \%)$ were recorded during the sampling (Fig. 2). Lauraceae with 6 species was the dominant family followed by Betulaceae and Rosaceae (4 species each). In Q. floribunda dominated 
Tab. 2. Summery of plant diversity and forest characteristics of tree species across various oak forests

\begin{tabular}{cccc}
\hline Parameters & Q. leucotrichophora forest & Q.floribunda forest & Q. semecarpifolia forest \\
\hline Number of families & 26 & 20 & 12 \\
\hline Number of genera & 40 & 30 & 16 \\
\hline Species richness & 54 & 43 & 23 \\
\hline Tree Density (ind./ha) & 415 & 422 & 333 \\
\hline Total Basal Area (m²/ha) & 88.06 & 110.5 & 123.8 \\
\hline Tree Seedling Density (ind./ha) & 1981 & 1475 & 348 \\
Tree Sapling Density (ind./ha) & 513 & 338 & 253 \\
\hline & Diversity indices (Tree): & 2.53 & 1.41 \\
\hline Shannon diversity index & 2.66 & 0.67 & 0.45 \\
\hline Pielou's evenness index & 0.67 & & \\
\hline
\end{tabular}

forests, 43 tree species (30 genera and 20 families) were found in systematic survey, while 34 species (79\%) were recorded during the sampling in the region. Lauraceae $(8$ species) was the dominating family in Q. floribunda forests followed by Aceraceae ( 4 species), Betulaceae, Fagaceae and Symplocaceae (3 species each). In Q. semecarpifolia dominating forests a total of 23 tree species belonging to 16 genera and 12 families were recorded, where 17 species (74\%) were recorded during the sampling. Ericaceae (3 species) was the dominating family followed by Aceraceae, Rosaceae and Pinaceae (2 species each). Pinaceae and Taxaceae were only two gymnospermic family represented by Pinus roxburghii in Q. leucotrichophora, Abies pindrow in Q. floribunda, A. spectabilis and Taxus wallichiana in Q. semecarpifolia dominated forests (Tab. 1). ShannnonWiener's Diversity Index varied from a minimum of 1.41 in Q. semecarpifolia forests at $2700-3300 \mathrm{~m}$ altitude to a maximum of 2.66 in Q. leucotrichophora dominated forests at 1400-2200 m elevation, similarly Pielou's Evenness Index varied from a minimum of 0.45 in Q. semecarpifolia forests to 0.67 in Q. floribunda and Q. leucotrichophora forests (Tab. 2).

\section{Density}

The overall tree density across various oak forests was estimated; where maximum tree density was recorded in Q. leucotrichophora and Q. floribunda dominated forests (433 individuals/ha each) followed by Q. semecarpifolia (335 individuals/ha) forests. In Q. leucotrichophora dominated forests, Q. leucotrichophora (65 individuals/ha), Rhododendron arboreum (60 individuals/ha) and Lyonia ovalifolia ( 57 individuals/ha) had the highest density and together accounted $43 \%$ of the total forest density. In $Q$. floribunda dominated forests $R$. arboreum (101 individuals/ha), L. ovalifolia (61 individuals/ha), Q. floribunda (50 individuals/ha), and Q. semecarpifolia (43 individuals/ha) accounted for $60 \%$ of the forest density, while in Q. semecarpifolia dominated forests only Q. semecarpifolia (142 individuals/ha) and $R$. arboreum (129 individuals/ha) accounted $80 \%$ of the total forest density (Tab. 3 ).

\section{Regeneration and population structure}

Overall density of regenerating individuals decreases with increasing elevation, where maximum seedlings (1981 individuals/ha) and saplings (513 individuals/ha) were recorded in Q. leucotrichophora forests followed by $Q$. floribunda (1475 individuals/ha seedlings, 338 individuals/ha saplings) and Q. semecarpifolia (348 individuals/ha seedlings, 253 individuals/ha saplings) forests. In Q. leucotrichophora forests Neolitsea cuipala (362 individuals/ha) and Q. leucotrichophora (322 individuals/ha) had highest seedling density and together accounted for $34 \%$ of the forest seedling density, whereas in Q. floribunda forests highest seedling density shown by Symplocos ramosissima (341 individuals/ha) and Neolitsea pallens (278 individuals/ha) accounted for $41 \%$ of the forests. At higher altitude, Q. semecarpifolia (232 individuals/ha) accounted for highest (66\%) seedling density to its own forests (Tab. 4). The different girth class trees of various oak forests showed
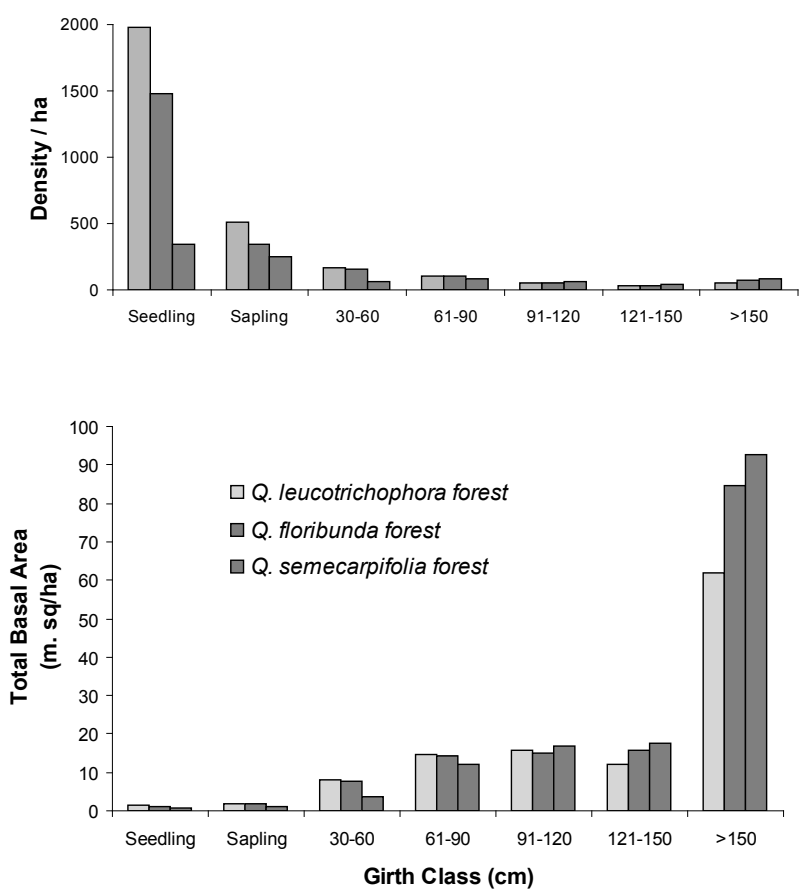

Fig. 3. Distribution of species density and total basal area in different girth classes in various oak forests 
Tab. 3. Density and Total Basal Area (TBA) with average height (Av. ht) of dominant tree species across various oak forests

\begin{tabular}{|c|c|c|c|c|c|c|}
\hline \multirow{2}{*}{ Species } & \multicolumn{2}{|c|}{ Q. leucotrichophora forest } & \multicolumn{2}{|c|}{ Q. floribunda forest } & \multicolumn{2}{|c|}{ Q. semecarpifolia forest } \\
\hline & Mean D/ha \pm SE & $\mathrm{TBA}(\mathrm{m})$ & Mean D/ha \pm SE & $\mathrm{TBA}(\mathrm{m})$ & Mean D/ha \pm SE & $\mathrm{TBA}(\mathrm{m})$ \\
\hline Abiespindrow & - & - & $10.88 \pm 2.91$ & 12.51 & $17.83 \pm 4.64$ & 6.42 \\
\hline Abies spectabilis & - & - & - & - & $14.44 \pm 4.49$ & 7.69 \\
\hline Acerpictum & - & - & $13.54 \pm 5.12$ & 3.83 & $0.85 \pm 0.67$ & 1.11 \\
\hline Acer sterculiaceum & $1.38 \pm 1.38$ & 0.91 & $3.72 \pm 1.87$ & 0.61 & - & - \\
\hline Aesculus indica & $0.69 \pm 0.69$ & 0.68 & $4.25 \pm 1.41$ & 4.46 & - & - \\
\hline Alnusnepalensis & $24.92 \pm 5.11$ & 13.19 & $3.18 \pm 2.01$ & 3.77 & - & - \\
\hline Betula alnoides & $4.15 \pm 1.41$ & 3.00 & $2.92 \pm 1.13$ & 0.45 & - & - \\
\hline Betula utilis & - & - & - & - & $0.42 \pm 0.34$ & 0.06 \\
\hline Carpinus viminea & $14.19 \pm 3.09$ & 3.41 & $9.02 \pm 3.38$ & 1.37 & - & - \\
\hline Dodecadenia grandiflora & $4.50 \pm 2.06$ & - & $5.31 \pm 1.9$ & 0.75 & $2.55 \pm 1.15$ & 0.18 \\
\hline Eurya acuminata & $5.88 \pm 2.41$ & 0.53 & $18.31 \pm 4.24$ & 1.28 & - & - \\
\hline Ilex dipyrena & $3.46 \pm 1.15$ & 0.45 & $19.11 \pm 3.34$ & 2.41 & $2.97 \pm 0.98$ & 0.42 \\
\hline Litsaea lanuginosa & $48.12 \pm 8.56$ & 3.77 & $15.39 \pm 4.86$ & 1.17 & - & - \\
\hline Lyonia ovalifolia & $58.16 \pm 9.22$ & 13.18 & $63.69 \pm 9.95$ & 9.42 & $4.67 \pm 2.17$ & 0.49 \\
\hline Meliosma pungens & $5.88 \pm 2.2$ & 0.60 & $0.53 \pm 0.53$ & 0.01 & - & - \\
\hline Neolitsea cuipala & $10.38 \pm 2.5$ & 1.68 & $6.90 \pm 1.90$ & 0.74 & - & - \\
\hline Neolitsea pallens & $1.04 \pm 1.04$ & 0.02 & $1.33 \pm 0.84$ & 0.04 & - & - \\
\hline Prunus cornuta & - & - & $3.18 \pm 1.62$ & 0.59 & $1.27 \pm 0.75$ & 0.14 \\
\hline Pyruspashia & $14.89 \pm 3.13$ & 1.68 & $2.65 \pm 1.04$ & 0.59 & - & - \\
\hline Quercusfloribunda & $11.42 \pm 3.74$ & 6.78 & $50.69 \pm 7.29$ & 23.73 & $4.67 \pm 2.38$ & 1.11 \\
\hline Q.lanca & $9.69 \pm 3.61$ & 3.59 & - & - & - & - \\
\hline Q. leucotrichophora & $66.81 \pm 10.95$ & 15.76 & $19.90 \pm 5.28$ & 5.83 & - & - \\
\hline Q. semecarpifolia & - & - & $43.79 \pm 6.78$ & 16.82 & $142.25 \pm 12.36$ & 51.21 \\
\hline Rhododendron arboreum & $60.58 \pm 12.28$ & 10.47 & $101.11 \pm 12.23$ & 16.89 & $132.06 \pm 13.97$ & 18.53 \\
\hline Sorbus cuspidata & - & - & $0.80 \pm 0.46$ & 0.06 & $3.40 \pm 1.76$ & 1.44 \\
\hline Symplocos chinensis & $3.46 \pm 2$ & 0.25 & $5.57 \pm 1.58$ & 0.36 & - & - \\
\hline Symplocos racemosa & $9 \pm 3.1$ & 0.43 & $13.80 \pm 4.46$ & 0.82 & - & - \\
\hline Taxus baccata & - & - & $1.06 \pm 0.52$ & 1.14 & $2.12 \pm 0.87$ & 1.09 \\
\hline Other & $75.12 \pm 13.5$ & 7.68 & $12.48 \pm 5.46$ & 0.83 & $8.49 \pm 4.5$ & 0.27 \\
\hline${ }^{*}$ Total & $433.72 \pm 93.13$ & 88.06 & $433.15 \pm 92.11$ & 110.47 & $337.99 \pm 51.03$ & 90.16 \\
\hline
\end{tabular}

$p>0.05$ (not significant) (one way ANOVA)

that, $41 \%$ of the total stem in Q. leucotrichophora and 37\% of stem in Q. floribunda dominated forests were between 30-60 cm girth class, whereas, in Q. semecarpifolia forest only $19 \%$ of the total stem were in 30-60 cm girth class.

The density-diameter distribution yielded reverse Jshaped curves in all three forest types. Despite the density of seedlings, saplings and lower girth class trees being very high, their total basal area was much less than the basal area of the matured and old growth trees, thereby resulting in J-shaped distribution of basal area (Fig. 3).

\section{Discussion}

At elevations ranging from $1000 \mathrm{~m}$ to the timber line (approx. $3500 \mathrm{~m}$ ) in the Garhwal Himalaya, one or the other species of oak (Quercus spp.) forms the climax vegetation (Champion and Seth, 1968; Troup, 1921). The natural oak forests of the Garhwal Himalaya are multilayered temperate evergreen forests, composed of large and small trees distributed in two distinct strata. The canopy and under-canopy tree layers were composed of large $(>15$ $\mathrm{m}$ height $)$ and small ( $<15 \mathrm{~m}$ height $)$ trees. The high species richness and density of the under-canopy tree layer is attributed to the presence of overhead canopy. These are either young or whose growth was arrested due to heavy shade by the overhead canopy in the lower altitudinal region. A total of 54 tree species in Q. leucotrichophora, 43 tree species in Q. floribunda and 23 tree species in Q. semecarpifolia dominated forests were recorded. The presence of higher number of tree species in Q. leucotrichophora and Q. floribunda dominated forests indicates the importance of wide range of distribution of many woody species and availability of high mesic condition. Whereas, $Q$. semecarpifolia dominated forests were inhabited in a wide range of distribution but in less favourable microclimatic condition. It is well-known that in the sub-alpine (2700-3300 $\mathrm{m}$ ) zone microclimate has a greater role in the distribution of the species than the climate of the region (Ludwig and 
Tab. 4. Density of regenerating individuals (individuals/ha) of dominant tree species across various oak forests

\begin{tabular}{|c|c|c|c|c|c|c|}
\hline \multirow[b]{2}{*}{ Species } & \multicolumn{2}{|c|}{ Q. leucotrichophora forest } & \multicolumn{2}{|c|}{ Q. floribunda forest } & \multicolumn{2}{|c|}{ Q. semecarpifolia forest } \\
\hline & $\begin{array}{l}\text { Seedlings } \\
\text { (ind./ha) }\end{array}$ & $\begin{array}{l}\text { Saplings } \\
\text { (ind./ha) }\end{array}$ & $\begin{array}{l}\text { Seedlings } \\
\text { (ind./ha) }\end{array}$ & $\begin{array}{l}\text { Saplings } \\
\text { (ind./ha) }\end{array}$ & $\begin{array}{l}\text { Seedlings } \\
\text { (ind./ha) }\end{array}$ & $\begin{array}{l}\text { Saplings } \\
\text { (ind./ha) }\end{array}$ \\
\hline Abies spectabilis & - & - & - & - & 1.70 & 3.40 \\
\hline Acerpictum & - & - & 69.00 & 9.55 & 1.70 & - \\
\hline Aesculus indica & 36.00 & - & 9.55 & - & - & - \\
\hline Daphniphyllum himalayanse & 34.62 & 24.92 & - & - & - & - \\
\hline Dodecadenia grandiflora & 38.77 & 16.62 & - & - & - & - \\
\hline Eurya acuminata & 60.92 & 5.54 & 38.22 & 13.80 & - & - \\
\hline Ilex dipyrena & 23.54 & 2.77 & 154.99 & 23.35 & 28.87 & 28.87 \\
\hline Lyonia ovalifolia & 12.46 & 30.46 & 16.99 & 7.43 & - & 3.40 \\
\hline Meliosma pungens & 27.69 & 12.46 & - & - & - & - \\
\hline Myrica esculenta & 42.92 & 8.31 & - & - & - & - \\
\hline Neolitsea cuipala & 362.78 & 77.54 & 92.36 & 22.29 & - & 1.70 \\
\hline Neolitsea pallens & 256.16 & 16.62 & 278.13 & 98.73 & - & - \\
\hline Persea odoratissima & 55.39 & 2.77 & - & - & - & - \\
\hline Pyruspashia & 67.85 & 27.69 & 9.55 & 4.25 & - & - \\
\hline Quercusfloribunda & 78.93 & 2.77 & 205.94 & 12.74 & - & - \\
\hline Quercus glauca & 132.93 & 4.15 & - & - & - & - \\
\hline Quercus lencotrichophora & 322.63 & 70.62 & 23.35 & 13.80 & - & - \\
\hline Quercus semecarpifolia & - & - & 77.49 & 81.74 & 232.70 & 52.65 \\
\hline Rhododendron arboreum & 74.77 & 27.69 & 49.89 & 18.05 & 81.53 & 139.28 \\
\hline Symplocos ramosissima & 261.70 & 112.16 & 341.83 & 21.23 & - & - \\
\hline Others & 91.39 & 70.62 & 108.28 & 11.68 & 1.70 & 23.78 \\
\hline${ }^{*}$ Total & 1981.45 & 513.71 & 1475.58 & 338.64 & 348.20 & 253.08 \\
\hline
\end{tabular}

$p<0.05$ for seedlings and $p>0.05$ for saplings (One way ANOVA)

Reynolds, 1988). Similar observations have been also reported from other temperate forests of the Western Himalaya (Singh and Singh, 1992; Zobel and Singh, 1997) and mountain humid forests of Meghalaya, northeast India (Jamir et al., 2006; Mishra et al., 2005).

Species diversity is one of the most important measures of community structure and it has been related to succession, stability and primary productivity. The diversity of trees is fundamental to forest diversity because they provide resources and habitats for almost all other species (Huston, 1994). Tree species diversity along the altitudinal gradient in various oak forests varied from a minimum of 1.41 in Q. semecarpifolia forests at 2700-3300 m altitude to a maximum of 2.66 in Q. leucotrichophora dominated forests. The lower species diversity in Q. semecarpifolia forests indicates heterogeneous distribution of the species. The dominance of Q. semecarpifolia indicates a suitable habitat for only this species and other species have existed only in very small patches, while in Q. leucotrichophora dominated forests undulating gentler terrain supports a greater number of species to distribute evenly and also increases species diversity. The lower diversity in Q. semecarpifolia forested region could be due to lower rate of evolution and diversification of communities (Simpson, 1965) and severity in the environment (Connell and Orias, 1964). The species richness and diversity index values in the Kedarnath WS fall within the range of values (tree species richness
9-28 and species diversity $0.8-3.4)$ recorded by Ralhan et al. (1982), Saxena and Singh (1982), Tewari (1982) and Upreti et al. (1985) for temperate forests of the Himalaya and are less than those (species diversity 3.5-5.4) recorded for moist tropical forests by Mishra et al. (2005) and Singh et al. (1981).

Lauraceae and Betulaceae in Q. leucotrichophora, Lauraceae and Aceraceae in Q. floribunda dominated forests were the dominant and co-dominant tree species families, while in Q. semecarpifolia forests the Ericaceae was the dominant family. This corroborates the result of Uniyal (2001) in Bhagirathi catchment, Uttarakhand, Singh (1999) in GHNP, Himachal Pradesah and Upadhaya et al. (2003) in Jainta hills in Meghalaya, who also recorded these families as dominant and co-dominant in the region.

Q. leucotrichophora and Q. floribunda dominated forests between 1400-2700 m altitude exhibit the maximum tree density (433 individuals/ha). Q. leucotrichophora was greatest at the hill base and lowest on the hill top. Whereas, Q. floribunda does not form mono stand and mixed with member of Lauraceae and Symplocaceae families. The lowest density ( 337 individuals/ha) of tree species was recorded in the Q. semecarpifolia forests at high altitude (>2700 $\mathrm{m}$ ) region. Q. semecarpifolia (132 individuals/ha) with associations of Rhododendron arboreum (132 individuals/ha) dominating the forests. There was no signifi- 
Tab. 5. Data on tree density and total basal area (TBA) of oak forest in the Uttarakhand Himalaya

\begin{tabular}{|c|c|c|c|}
\hline Locality & Density/ha & $\operatorname{TBA}\left(\mathrm{m}^{2} / \mathrm{ha}\right)$ & Author and year \\
\hline \multicolumn{4}{|c|}{ Q. leucotrichophora forests } \\
\hline Maheshkhan (Nainital) & 940 & 39.4 & Saxena and Singh 1982 \\
\hline Chambhi (Nainital) & 416 & 32.71 & Ralhen et al. 1982 \\
\hline Kunjakharak (Nainital) & 830 & 30.69 & Rikhari et al. 1991 \\
\hline Siahidevi (Almora) & 1260 & 31.7 & Rana et al. 1985 \\
\hline Shitalakhet (Almora) & 880 & 56.37 & Pandey 2003 \\
\hline Mandal (Chamoli) & 340 & 25 & Ghildiyal et al. 1998 \\
\hline Pauri (Pauri Garhwal) & 730 & 43.96 & Srivastava et al. 2005 \\
\hline Pauri (Pauri Garhwal) & 390 & 17.27 & Dhanai et al. 2000 \\
\hline Buvakhal (Pauri Garhwal) & 790 & 35.39 & Kusumlata and Bisht 1991 \\
\hline Mussoorie (Dehradun) & 640 & - & Joshi et al. 1985 \\
\hline Dhanolti (Dehradun) & 140 & 13.55 & Singhal and Soni 1989 \\
\hline Mandal-Tungnath (Chamoli) & 433 & 88.06 & Present study \\
\hline \multicolumn{4}{|c|}{ Q. floribunda forests } \\
\hline Maheshkhan (Bhawali) & 1300 & 83.77 & Saxena and Singh 1982 \\
\hline Garhwal Himalaya (Pauri) & $220-640$ & $23.53-43.24$ & Sharma et al. 2001 \\
\hline Dudhatoli region (Dehradun) & $250-340$ & $18.45-38.25$ & Baduni and Sharma 1996 \\
\hline Kumaun region & $320-1960$ & $37-95$ & Singh et al. 1994 \\
\hline Dhakuri (Pindari) & 1060 & 98.49 & Kalakoti et al. 1986 \\
\hline Mandal-Tungnath (Chamoli) & 433 & 110.47 & Present study \\
\hline \multicolumn{4}{|c|}{ Q. semecarpifolia forests } \\
\hline Chakrata (Dehradun) & 320 & 29.19 & Singhal et al. 1986 \\
\hline Binsar Mahadev (Pauri) & $310-520$ & $31.50-57.33$ & Baduni and Sharma 1996 \\
\hline Kumaun region & $250-2070$ & $5-114$ & Singh et al. 1994 \\
\hline Pindari (Bageshwar) & 480 & 73.4 & Adhikari et al. 1995 \\
\hline Askot WS (Pithoragarh) & 550 & 50.8 & Dhar et al. 1997 \\
\hline Kedarnath WS (Chamoli) & $340-810$ & $30.1-62.2$ & Rai et al. 2012 \\
\hline Mandal-Tungnath (Chamoli) & 337 & 90.16 & Present study \\
\hline
\end{tabular}

cant variation (one way ANOVA, $p=0.8$ ) between overall tree density in different oak forests. The total basal area of Q. leucotrichophora $\left(88.06 \mathrm{~m}^{2} / \mathrm{ha}\right)$, Q. floribunda (110.47 $\mathrm{m}^{2} / \mathrm{ha}$ ) and Q. semecarpifolia $\left(90.12 \mathrm{~m}^{2} / \mathrm{ha}\right)$ dominated forests with low tree density of $433.72,433.15$ and 337.99 individuals/ha respectively, showed that there were high density of higher girth class trees in the region. The total basal area reported in all the three oak dominated forests were slightly higher than those of earlier values (35.0 to $83.8 \mathrm{~m}^{2} / \mathrm{ha}$ ) reported by various authors (Tab. 5) for the Himalayan forests.

The density-distribution curve of the tree species showed that there are higher numbers of seedlings in $Q$. leucotrichophora and Q. floribunda forests than in the $Q$. semecarpifolia forests, which is comparable to the other studies of the Himalayan region (Thadani and Ashton, 1995). Low number of seedlings (348 individuals/ha) and saplings (253 individuals/ha) in Q. semecarpifolia forests could be due to excessive grazing by local as well as migratory livestock in the region (Singh, 2008; Singh $e t$ al., 2010). The seedlings density has significant variation $(p=0.01)$ in different oak forests. Highest seedling density was recorded in Q. leucotrichophora forest (1981 individuals/ha) and lowest in Q. semecarpifolia forests (348 indi- viduals/ha). Sapling density did not show any significant variation $(p>0.05)$ across various oak forests in the region with highest density recorded in $Q$. leucotrichophora forests (1981 individuals/ha) and lowest in Q. semecarpifolia forests (348 individuals/ha).

Based on this distribution curve one can predict the species showing expanding or stable type of population structure, since they have a sufficient number of individuals in younger classes to replace those in older classes. Comparison of total basal area and girth classes distribution showed that, high basal area cover was recorded in the higher girth class trees of all the three oak dominated forests.

\section{Conclusions}

Among all the oak forests of the region, Q. leucotrichophora dominating forests are slightly richer in terms of tree species richness and diversity than Q. floribunda and $Q$. semecarpifolia forests. The distribution of tree species (54 tree spp. in Q. leucotrichophora, 43 tree spp. in $Q$. floribunda and 23 tree spp. in Q. semecarpifolia dominated forests) in these forests stands was governed mainly by the gradient of altitude. Member of Lauraceae family were the 
most dominant tree species in the Q. leucotrichophora and Q. floribunda forests. The regenerating individuals and higher girth class trees were high in these forests because of mesic condition. Although the entire forested area seems protected and natural, the low seedling/sapling density in Q. semecarpifolia forests is a matter of concern and needs some protection from grazing in the early stage of plant growth.

\section{Acknowledgements}

We are thankful to UCOST, Govt. of Uttarakhand and Department of Science and Technology, Govt. of India for funding (No. SR/FT/LS-054/2009).

\section{References}

Adhikari BS, Rawat YS, Singh SP (1995). Structure and function of high altitude forests of Central Himalaya I. Dry matter Dynamics. Annals of Botany 72:237-248.

Baduni NP, Sharma CM (1996). Effect of aspect on the structure of some natural stands of Cupressus torulosa in Himalayan moist temperate Forest. Proc Ind Nat Sci Acad 62:345352.

Champion HG, Seth SK (1968). A revised survey of the forest types of India. Manager of Publications, Govt. of India, New Delhi.

Chandra R, Upadhyay VP, Bargali SS (1989). Analysis of Herbaceous Vegetation under Oak and Pine forests along an altitudinal gradient in Central Himalaya. Envir Eco 7(3):521525.

Connell JH, Orias E (1964). The ecological regulation of species diversity. Amer Natur 48:399-414.

Dhanai CS, Panwar VP, Sharma CM (2000). Effect of aspect and soil on the structure of Quercus leucotrichophora natural stands in western Himalaya. Indian Journal of Forestry 23(3):349-356.

Dhar U, Rawal RS, Samant SS (1997). Structural diversity and representative ness of forest vegetation in a protected area of Kumaun Himalaya, India: implications for conservation. Biodiversity and Conservation 6:1045-1062.

Ghildiyal S, Baduni NP, Khanduri VP, Sharma CM (1998). Community structure and composition of oak forests along altitudinal gradient in Garhwal Himalaya. Indian Journal of Forestry 21(3):242-247.

Gupta RK, Singh JS (1962). Succession of vegetation types in the Tones valley of the Garhwal Himalayas. Indian Forester 88:289-296.

Huston MA (1994). Biological diversity: the coexistence of species in changing landscapes. Cambridge University Press, Cambridge.

Jain SK, Rao RR (1976). A Handbook of Field and Herbarium Method. New Delhi.

Jamir SA, Upadhaya K, Pandey HN (2006). Life form composition and stratification of montane humid forests in Megha- laya, northeast India. Tropical Ecology 47:183-190.

Joshi SP, Raizada A, Srivastava MM (1985). Vegetational analysis of oak forest at Mussoorie (Barlowganj), India. Indian Journal of Forestry 8(1):78-84.

Kalakoti BS, Pangtey YPS, Saxena AK (1986). Quantitative analysis of high altitude vegetation of Kumaun Himalaya. Journal of Indian Botanical Society 65:384-396.

Kershaw KA (1973). Quantitative and Dynamic Plant Ecology. Edward Arnold Ltd London.

Kusumlata G, Bisht NS (1991). Quantitative analysis and regeneration potential of moist temperate forest in Western Himalaya. Ind J For 14(2):98-106.

Ludwig JA, Reynolds JF (1988). Statistical ecology: a primer on methods and computing. Wiley, New York.

Mishra BP, Tripathi OP, Laloo RC (2005). Community characteristics of a subtropical forests of Meghalaya and population structure of ten important tree species. Biodiversity and Conservation 46:241-251.

Mishra R (1968). Ecology Work Book. Oxford Publishing Company, Calcutta, India.

Muller-Dombois D, Ellenberg H (1974). Aims and Methods of Vegetation Ecology. John Wiley and Sons.

Naithani BD (1984). Flora of Chamoli, Botanical Survey of India, Dehra Dun, vol. 1 and 2.

Osmaston AE (1927). A forest flora for Kumaon. London.

Pandey JC (2003). Vegetation analysis in a mixed oak conifer forest of central Himalaya. Indian Journal of Forestry 26(1):66-74.

Pielou EC (1966). The measurement of diversity in different types of biological collections. Journal Theoretical Biology 13:131-144.

Polunin O, Stainton A (1984). Flowers of Himalaya. Oxford University Press New Delhi. 580.

Rai ID, Adhikari BS, Rawat GS, Kiran B (2012). Community Structure along Timberline Ecotone in Relation to Microtopography and Disturbances in Western Himalaya. Not Sci Biol 4(2):41-52.

Ralhan PK, Saxena AK, Singh JS (1982). Analysis of forest vegetation at and around Nainital in Kumaun Himalaya. Proc Ind Nat Sci Acad 48:122-138.

Rana BS, Verma KR, Pandey AN (1985). Analysis of forest vegetation at Siahi Devi Hill of west Almora division in Kumaun Himalaya. Indian Forester 111(9):745-759.

Rawat YS, Singh JS (1988). Structure and function of oak forests in the Central Himalaya. I- Dry matter dynamics. Annals of Botany 62:397-411.

Rikhari HC, Tewari JC, Rana BS, Sharma S (1991). Woody vegetation and regeneration status in a mixed oak forest of Kumaun Himalaya. Indian Forster 117(4):274-283.

Saxena AK, Singh JS (1982). A phytosociological analysis of woody species in forest communities of a part of Kumaun Himalaya. Vegetatio 50:3-22. 
140

Saxena HO, Srivastava PBL (1973). Forest communities of Mussoorie. Tropical Ecology 14(2):197-218.

Shannon CE, Weaver W (1949). The Mathematical Theory of Communication, University of Illinois Press, Urbana, Illinois.

Sharma CM, Khanduri VP, Goshwami S (2001). Community composition and population structure in temperate mixed broad-leaved and coniferous forest along an altitudinal gradient in a part of Western Himalaya. J Hil Res 14(1):32-43.

Simpson GG (1965). The geography of evolution. Chilton, Philadelphia.

Singh G (2008). Diversity of vascular plants in some parts of Kedarnath Wildlife Sanctuary (Western Himalaya), Ph.D. Thesis, Kumaun University Nainital.

Singh G, Rawat GS, Verma D (2010). Comparative study of fuelwood consumption by villagers and seasonal "Dhaba owners" in the tourist affected regions of Western Himalaya, India. Energy Policy 38:1895-1899.

Singh JS (1981). Rural ecosystems and development in the Himalaya, 74-87 p. In: Singh JS, Singh SP, Shastri C (Eds.). Science and Rural Development in Mountains. Gyanodaya Prakashan, Nainital, India.

Singh JS, Singh SP (1992). Forests of Himalaya: Structure, Functioning and Impact of Man, Gyanodaya Prakashan, Nainital.

Singh JS, Singh SP (1986). Structure and function of the Central Himalayan Oak forests. Proc Ind Acad Sci 96(3):156189.

Singh JS, Singh SP (1987). Forest Vegetation of the Himalaya. Botanical Rev 53(1):80-192.

Singh SP, Adhikari BS, Zobel DB (1994). Biomass, productivity, leaf longevity, and forest structure in the Central Himalaya. Ecological Monographs 64:401-421.

Singh SK (1999). A study on the plant community composition and species diversity in Great Himalayan National Park, western Himalaya. Ph.D. Thesis, Kumaun University Nainital.

Singhal RM, Soni S (1989). Quantitative ecological analysis of some woody species of Mussoorie Himalaya (U.P.). Indian Forester 115(5):327-337.
Singhal RM, Rawat VRS, Kumar P, Sharma SD, Singh HB (1986). Vegetation analysis of woody species of some forest of Chakarta Himalaya, India. Indian Forester 112:819-823.

Sharma CM, Khanduri VP, Goshwami S (2001). Community composition and population structure in temperate mixed broad-leaved and coniferous forest along an altitudinal gradient in a part of Garhwal Himalaya. Journal of Hill Research 14(1):32-43.

Srivastava RK, Khanduri VP, Sharma CM, Kumar P (2005). Structure, Diversity and Regeneration Potential of oak Dominant Conifer Mixed Forests along an Altitudinal Gradient in Western Himalaya. The Indian Forester 105 (6):1537-1553.

Thadani R, Ashton PMS (1995). Regeneration of Banj oak (Quercus leucotrichophora A. Camus) in the Central Himalaya. Forest Ecology and Management 78:217-224.

Tiwari AK, Singh JC (1984). Mapping forest biomass in India through areal photographs and non-destructive field sampling. Appl Geogr 4:151-165.

Troup RS (1921). Silviculture of Indian Trees. Vol. I-III. Clarendon Press, Oxford.

Uniyal SK (2001). A study on the structure and composition of forests along an altitudinal gradient in upper Bhagirathi catchment, Garhwal Himalaya. Ph. D., Thesis, FRI, Deemed University Dehra Dun.

Upadhaya K, Pandey HN, Law PS, Tripathi RS (2003). Tree diversity in sacred grooves of the Jaintia hills in Meghalaya, northeast India. Biodiversity and Conservation 12:583 597.

Upreti N, Tewari JC, Singh SP (1985). The oak forests of the Kumaun Himalaya (India): composition, diversity and regeneration. Mt Res Dev 5(2):163-174.

Whittaker RH (1972). Evolution and measurement of species diversity. Taxon 21:213-251.

Zobel BD, Singh SP (1997). Himalayan Forests and Ecological Generalizations. Bio Science 47(11):735-745. 